\title{
Generating motivation in minor language education: A case of Hungarian in Japan
}

\author{
MARI OKAMOTO \\ Osaka University
}

\begin{abstract}
In this paper I describe the landscape of Hungarian language in Japan and analyse problems that occur. I describe my teaching experience at a Japanese university and suggest an effective manner of teaching a minor language, in terms of both goal setting and methodology. Specifically, I present a potentially effective pedagogy to instruct minor languages, which I have adopted in my bilingual booklets projects. Bilateral activities between language learners and target language speakers are utilized in this project, which ultimately promote language learning motivation.
\end{abstract}

Keywords: Hungarian language teaching; Japanese; ultra-minor languages; Hungarian-Japanese bilateral learning; bilingual project

\section{Hungarian language instruction in Japan}

Let us begin by reviewing Hungarian language education around the world. Hungarian language teaching may be classified into four types. The first type is Hungarian teaching within Hungary. Foreigners who live in Hungary need to learn the language to some degree, although their purpose and expected level of acquisition may vary. For example, some people need Hungarian as a communication tool for employment, 
while others may have a Hungarian partner. The second type is Hungarian education for people of Hungarian descent in neighbouring countries. The maintenance of their mother tongue has been an important mission for many Hungarologists within and outside of Hungarian borders for a century. ${ }^{1}$ The third type is Hungarian education in other European countries and North America. These countries all have a substantial history with Hungary. Firstly, a number of Hungarian immigrants currently reside in these countries and have tried to maintain their language and culture for many generations. Secondly, some countries have a linguistic connection with Hungarian: in Finland, Estonia, and Russia, Finno-Ugric languages are spoken either as the state language or by various ethnicities within their borders. Hungarian and Finno-Ugric comparative linguistics are taught at several universities. In all of the above three contexts, learners often feel deeply connected to Hungarian and have a relatively strong motivation to learn it. For example, ethnic Hungarians living in other countries place importance on maintaining their mother tongue, while foreigners living in Hungary need to learn the language for daily functions.

The fourth and final context of Hungarian language is that in countries that are far from Hungary. East Asian countries (e.g. South Korea, China, and Japan) belong to this category. In these countries Hungarian education is, surprisingly, fairly systematized: national universities have a Hungarian department, to which a fixed number of students are regularly admitted and graduate. ${ }^{2}$ At Osaka University's Hungarian department, the only Japanese university where Hungarian is taught regularly

\footnotetext{
$1 \quad$ With regard to mother tongue maintenance, É. Kiss (2004: 124-5) states that the main difficulty with the mother tongue maintenance of ethnic Hungarians in the neighboring countries lies in its restricted usage in the society, rather than the increasing variation due to contact with the state languages. Hungarian is often merely the language used within the family and lacks the terminology for higher level social activities, such as higher education, the various fields of science, judicial and administrative affairs, etc.

2 See, for example, the Hungarian education at the School of European Languages and Cultures at Beijing Foreign Studies University in China (http://global.bfsu.edu.
} 
as a major, approximately 18 freshmen are welcomed each year. ${ }^{3}$ We are fortunate to have highly active and hard-working students, nearly half of whom have opportunities to be awarded scholarships and study in Hungary for a year during their university program. In this sense Osaka University is favoured with good conditions. However, we do experience challenges unique to our context due to Japan's linguistic environment. In the following section, we will take a closer look at the foreign language education landscape in Japan.

\section{The position of Hungarian in foreign language education in Japan}

Unlike many European countries, Japan has no strong historical or cultural relations with Hungary: there are no Hungarian immigrants nor their descendants, so the learners of the language are not genetically related to Hungarians, nor do they have any strong social, economic, or cultural ties with Hungary. The number of learners is also small, as reflected by the 18 freshmen in our Hungarian department. This number is particularly small, as Japanese universities admit half a million students annually.

Let us consider the position the Hungarian language occupies in Japan. Due to historic reasons, Japan's foreign language education has been overwhelmingly English-dominant. Before the mid-19th century, with foreign trade severely restricted for centuries, Chinese and Dutch were among the few tools available for access to 'higher' sciences, such as philosophy and medical science. ${ }^{4}$ These were eventually replaced by

$\mathrm{cn} / \mathrm{en} / \mathrm{p} \mathrm{p}=343$ ) and the Hungarian major at Hankuk University of Foreign Studies in South Korea (http://www.hufs.ac.kr/user/hufsenglish/un_2_c_5b.jsp).

3 Information regarding the academic structure at the School of Foreign Studies at Osaka University, Japan, is available at http://www1.lang.osaka-u.ac.jp/en/outlines/ education_org.html.

4 From the beginning of 17 th century to the middle of 19th century foreign trade with western countries except the Netherlands was prohibited. The main purpose of this policy was to prevent the 'threat' of the Catholic Church. In this period Dutch was 
German, French and mainly English, when the country began modernizing in the second half of the 19th century. Schools were founded in which foreign teachers taught western languages. Young intellectuals and politicians went to Europe (mainly to Germany, France, England, and the United States) to study modern laws, technology, social systems, and liberal arts. ${ }^{5}$ These European languages have thus been considered very important in higher education. This tendency persists today, as French and German are the most popular foreign languages after English at many universities.

During the 20th century, the strong cultural, political, and economic influence of the United States pushed English to the prime position. In junior high and high schools in Japan, English is actually the only compulsory language (Yamada 2015: 21-22). Japanese universities also require students to take English admission exams regardless of their major. As seen in Table 1, only between 100 and 400 students choose German, French, Chinese, or Korean for university entrance exams (centre admission), while more than half a million take the English exam.

TABLE 1. Number of examinees at university centre admission

\begin{tabular}{|l|r|r|r|r|r|}
\hline Language & \multicolumn{1}{c|}{$\mathbf{2 0 1 0}$} & $\mathbf{2 0 1 1}$ & $\mathbf{2 0 1 2}$ & \multicolumn{1}{c|}{$\mathbf{2 0 1 3}$} & \multicolumn{1}{c|}{$\mathbf{2 0 1 4}$} \\
\hline English & 512,451 & 519,538 & 519,867 & 535,835 & 525,217 \\
\hline German & 124 & 132 & 125 & 123 & 147 \\
\hline French & 165 & 151 & 142 & 151 & 134 \\
\hline Chinese & 364 & 392 & 389 & 445 & 449 \\
\hline Korean & 167 & 163 & 151 & 180 & 161 \\
\hline
\end{tabular}

Source: National Centre for University Entrance Examination

therefore the only tool for importing western sciences, such as medical and physical sciences (Miyanaga 2004: 113-180).

5 Many of these schools, founded around the Meiji Restoration (1868), later developed into today's colleges and universities, while the hundreds of young intellectuals sent to the West later became ministers, officials of the new government, and leading scholars and artists (Watanabe 1977). 
English education thus accounts for most foreign language education in Japan. For most Japanese individuals, the term 'foreign language' almost exclusively means English. ${ }^{6}$ This extremely homogeneous context of language education seems to be strengthening even further with globalization. Although the idea of multilingual and multicultural education is gradually spreading, this is focused mainly on Chinese and Korean, largely due to the economic relationship with the countries in which these languages are spoken.

Under these circumstances, Finno-Ugric languages - including Hungarian - are not only minor, but may be considered 'ultra-minor languages' in Japan. Even radical ideas regarding multilingual education do not include these languages. Hungarian could by no means be regarded as a practical tool of communication in Japan. The question then arises whether it is appropriate to approach Hungarian language instruction in the same way as that of major languages (e.g. English).

The study of language learning motivation has focused particularly on socio-psychological approaches, such as the integrative motive of becoming a member of the target language (Gardner \& Lambert 1972) and the motivational self system theory of becoming an ideal or oughtto self through language acquisition (Dörnyei \& Ushioda 2009); these are no doubt significant factors in language learning motivation, for

\footnotetext{
6 Today China and the South Korea could be characterised as heavily English-oriented in terms of foreign language education, as can Japan, but the historical process of foreign language education was different in each country. China, as the centre of Eastern civilization, neglected foreign language education for a long time. However, the socialist revolution of the middle 20th century brought exclusive Russian education, which was gradually followed by English. During the Cultural Revolution in the 1960s and 1970s, English education was prohibited, but since the 1990s, the economic reform has accelerated English language education once again. On the Korean Peninsula, in contrast, the strong Confucian influence allowed Chinese study to prosper for half a millenium, and this gradually shifted to the western languages at the end of the 19th century. However, during the colonization by Japan, the Japanese language was forced upon the whole of Korea. After the Second World War, the strong Americanisation and globalisation pushed English to the supreme position, as in Japan (Otani et al. 2004).
} 
example, in the case of English. However, in terms of learning Hungarian in Japan, these perspectives may not suffice. In the following section, I introduce some pedagogical ideas from my experience in teaching Hungarian to Japanese university students.

\section{Setting a different goal for language learning: The idea of ' $3 \mathrm{Cs}$ '}

In terms of setting a language learning goal, allow me to introduce the acronym ' $3 \mathrm{Cs}$ ', standing for communicative, creative, and contributive activities. These three concepts are derived from my own teaching experience connected to the project described in section 4 below.

Firstly, developing communicative skill is essential in language learning. For learners of major languages (e.g. English), this may be their only learning goal and can sufficiently motivate them to acquire the target language. However, for minor languages, an exclusively utilitarian goal may not always be sufficient, as students are often unsure to what extent they will realistically utilize the language. In addition to the communicative goal, we should be conscious of other possible motivations, and aim to provide additional goals for language learning.

With this in mind, I propose the remaining two 'Cs', namely, creative and contributive goals in language learning. Generally in language learning, the teacher provides learners with knowledge on how to use the target language. In this context, learners are passive: the knowledge goes in one direction from the target language to the learner, transferred through the teacher.

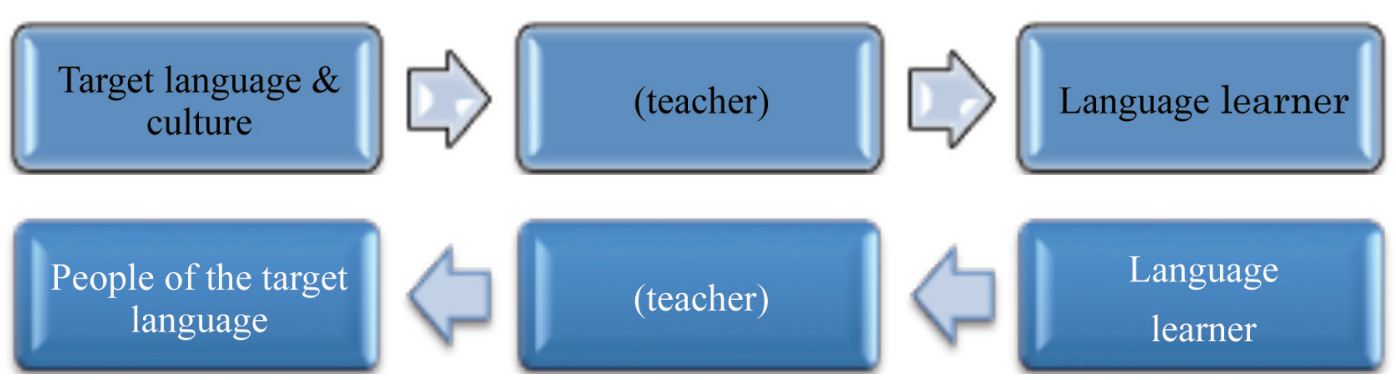

FIGURE 1. Creative and contributive goals of language learning 
What I aim to do is not only to ensure that Japanese students receive knowledge of Hungarian, but also to enable them to give certain knowledge back to Hungarians (that is, the speakers and the community of the target language), as shown in Figure 1. Language learning thereby becomes bilateral, and can be creative, as the learners are not merely receivers of knowledge, but can also be creators and senders of their own knowledge. This process is also contributive, as not only the learner benefits from the target language, but s/he can also provide benefit to target language speakers.

\section{Japanese-Hungarian bilingual projects thus far}

In order to put the latter two 'Cs' into practice, I have worked on what I call a 'bilingual project'. Since 2003, I have required my third- and fourth-grade students to produce a booklet about Japanese culture in Hungarian. Specifically, students are required to (1) select a subject, (2) write relevant material and translate it into Hungarian, and (3) produce the material in a booklet and dedicate it to the Hungarian community, specifically those learning Japanese. These steps are described in more detail in (1) to (3) below.

(1) Selecting a subject is the first and possibly the most difficult task. In order to choose content that will be attractive and useful for Hungarian learners of Japanese, the students review their own language and culture with a 'Hungarian' eye. They discuss what Hungarians may be interested in, what they might want to know about Japanese culture, and what problems they may have when learning Japanese. These questions allow students to notice things they were previously unconscious of regarding their own language and culture. Through this task, the students learn not only about the target language and its culture, but also their own. A list of selected subjects is given in Table 2. 
(2) Table 2. The list of bilingual projects since 2003:

2003 「日本語-ハンガリー語生活文化事典」Japán-magyar kulturális kislexikon

(A small encyclopaedia of Japanese culture)

2004 「日本人の名前事典」A japán utónevek szótára (Encyclopaedia of Japanese names)

2005 「ハンガリー民話集」Magyar népmesék (Hungarian folktales)

2006 「日本語擬音語・擬態語辞典」A japán hangulatfestő szavak szótára (Dictionary of Japanese onomatopoeia)

2007 「ンンガリー語身体表現ミニ辞典」A magyar testrésznevek-kifejezés szótára

(Dictionary of Hungarian body part expressions)

2008 「ハンガリー人のための日本の歩き方ガイド」Járunk-kelünk Japánban!

(Japan guide book for Hungarians)

2009「日本語ことわざ辞典」A japán szólások és közmondások kislexikona

(Dictionary of Japanese proverbs)

2010「ハンガリー人のための日本の生活お役立ち事典」Mit kell tudni a japán életről?

(What should you know about Japanese life?)

2011 「もしあなたが日本に生まれていたなら...」Ha Japánban születtél volna...

(If you were born in Japan...)

2012「ごはんですよ!」Jó étvágyat! (Enjoy your meal! -A guide for Japanese food)

2013 「色のいろイロ」Színekrők színesen (Encyclopaedia of color expressions)

2014「いまひとたびの百人一首」Százszorszép japán versek (Hyakunin-issu: A hundred Japanese poems by a hundred poets)

2015「なにわともあれ好きやねん大阪」Édes Oszakám!

(Osaka guide book for Hungarians)

(3) When the subject is decided, the students discuss the content and write the texts in both Japanese and Hungarian. This is a fairly difficult task, as the students have only learnt Hungarian for two or three years, and especially because they have to interpret and describe different aspects 
of Japanese culture in the target language. Fortunately Osaka University receives a few Hungarian students annually, who study Japanese language and culture. They have willingly participated in this project and have worked with the Japanese students every week.

In 2014 the students attempted to translate Hyakunin-isshu into Hungarian. ${ }^{7}$ The Hyakunin-isshu is an anthology consisting of a 100 short poems by 100 individuals written between the 10th and 14th centuries; the authors range from emperors, nobles, officials, priests, and poets to nameless soldiers. The topics of the poems also vary: many are about the passion of love, while others focus on the beauty of nature, or life and death. The original poems are written in medieval Japanese, requiring the students to look carefully into the language and understand the historical and cultural background of the poems. Moreover, each poem consists of five lines and has a 5-7-5-7-7 syllable structure, which is a traditional form of Japanese poetry. The students attempted to maintain the same syllabic pattern in the Hungarian translations. They also explained the meaning of the poems and the background of the given era and author. They worked with the Hungarian students to determine the best way to express each poem's meaning in Hungarian. The students wrote a short introductory essay for each poem in Hungarian, and produced hand-made cards by which the Hungarian learners of Japanese could become acquainted with the poems through playing cards.

(4) When the booklet is complete, it is printed and each student receives two copies: one for him/herself and one as a gift for a Hungarian friend learning about or interested in Japanese culture. Some students leave Japan shortly after the semester and take the booklet with them to Hungary as a 'souvenir'. I have also sent booklets to Hungarian educational institutions that teach Japanese.

\footnotetext{
7 See the Hyakunin-issu project on web at http://issuu.com/oszakamagyarszak/ docs/szazszorszepversek. The recent Osaka guidebook for Hungarians is also available at http://issuu.com/oszakamagyarszak/docs/_des_oszak_m.
} 


\section{The possibilities for 'ultra-minor' language education}

As seen above, the booklet projects allow Japanese students not only to learn the Hungarian language but also to create content on Japanese culture, and by doing so, to contribute to the target language community. This activity has been observed to increase students' motivation, as they are conscious that they are both learning the language and giving back to the Hungarian community, thus actively promoting mutual understanding between Japanese and Hungarian individuals. This is also clearly reflected by the Hungarian students who assist in the booklet production, as they often learn a lot from the Japanese students and become good friends through the project.

Ultimately, my goal in Hungarian teaching in Japan is that in the face of English domination in ever-expanding globalization, the few students learning minor languages may be able to sow small, precious seeds of multiculturalism in Japanese society.

\section{Acknowledgments}

This article is based mainly on a presentation at the XII. International Conference of Finno-Ugric Studies held at Oulu University (Finland) on 19th August 2015. My research is supported by JSPS KAKENHI Grant Number 15K02413.

\section{References}

Dörnyei, Zoltán, Ema Ushioda 2009. Motivation, Language Identity and the L2 Self. Clevedon: Multilingual Matters.

Education at a glance 2015. OECD indicators. http://www.keepeek.com/DigitalAsset-Management/oecd/education/education-at-a-glance-2015_eag2015-en

Fenyvesi, Kristóf, Tuomo Lahdelma (Eds.) 2013. Institutions, Tendencies and Research in the International Hungarian Studies: The First Twenty Years of the Jyväskylä University’s Hungarian Studies Program. Jyväskylä: University of Jyväskylä. http://urn.fi/URN:ISBN:978-951-39-5581-6 
Foreign language learning statistics. Eurostat statistics explained. http://ec.europa. eu/eurostat/statistics-explained/index.php/Foreign_language_learning statistics

Gardner, R. C., W. E. Lambert 1972. Attitudes and Motivation in Second-Language Learning. Newbury House Publishers.

Hatta, Yoko 2003. The issues of making English an official language and English education in Japan. - Journal of Bunkyo University 16 (2), 107-136.

Iwasaki, Katsumi 2007. The current state of second language education in Japanese universities, and one tentative plan for its reform. - Journal of Hiroshima University 10, 57-83.

Kiss, Katalin É. 2004. Anyanyelvünk állapotáról. Budapest: Osiris Kiadó.

Lahdelma, Tuomo, Sándor Maticsák (Eds.) 1995. Hungarológia Magyarországon kívül. Hungarologische Beiträge 4. Jyväskylä: Universität Jyväskylä.

Maeno, Sumiko 2006. Leading English educators in early Meiji era Japan. - Journal of Kamakura Women's University 13, 101-108.

Maticsák, Sándor (Ed.) 2007. Nyelv, nemzet, identitás. Az IV. Nemzetközi Hungarológiai kongresszus nyelvészeti előadásai. II. kötet. Budapest-Debrecen: Nemzetközi Magyarságtudományi Társaság. http://nbn.urn.hu/ N2L?urn:nbn:hu-7687

Miyanaga, Takashi 2004. Nihon Yogakushi ['History of Western Studies in Japan']. Sanshusha.

National Center for University Entrance Examination. http://www.dnc.ac.jp/

Otani, Yasuteru (Ed.) 2004. Language Teaching Policy in the 21st Century. Toshindo.

Watanabe, Minoru 1977. Kindai Nihon Kaigairyugakuseishi ['History of Studying Abroad in Modern Japan']. Kodansha.

White Paper on Education, Culture, Sports, Science and Technology. 2012 . http:// www.mext.go.jp/b_menu/hakusho/hakusho.htm

Yamada, Mieko 2015. The Role of English Teaching in Modern Japan. Routledge. 


\title{
Motivaation kehittäminen pienen kielen opettamisessa: unkarin kieli Japanissa
}

\author{
MARI OKAMOTO \\ Osakan yliopisto
}

Artikkelissa kuvaillaan unkarin kielen opetuksen ainutlaatuista asemaa Japanissa verrattuna toisiin yhteyksiin, esimerkiksi unkarin kielen opetukseen Unkarissa tai unkarilaisten ja unkarilaistaustaisten ryhmien unkarin taidon ylläpitämiseen Unkarin naapurimaissa tai Amerikassa. Japanissa kuten muuallakin Itä-Aasiassa unkarin kielen opetus on varsin systemaattisesti järjestetty, mutta tämä yksin ei riitä opiskelijoiden motivoimiseen, koska Unkarin ja näiden maiden välillä ei ole voimakkaita taloudellisia tai kulttuuriyhteyksiä.

Kuvaan tässä projektia, jota olen toteuttanut yli kymmenen vuoden ajan Osakan yliopiston unkarin laitoksen opiskelijoiden kanssa. Tuottamalla kaksikielisiä kirjasia, joilla Japanin kulttuuria esitellään unkarilaisille lukijoille, unkarin opiskelijat eivät vain opi kohdekieltä vaan myös antavat jotakin unkarin kielen puhujayhteisölle. Artikkelissa kuvaan, miten opiskelijat valitsevat aiheensa, tekevät yhteistyötä unkarilaisten opiskelijoiden kanssa ja välittävät työnsä tulokset unkarinkieliselle kohdeyleisölle. Tämä kommunikatiivinen, luova ja uutta tuottava kielenoppimismenetelmä pystyy motivoimaan opiskelijoita toisin kuin perinteiset menetelmät, koska se tekee kielenoppijoista oman kulttuurinsa aktiivisia välittäjiä.

Avainsanat: Unkarin kielen opetus; japanin kieli; harvemmin opetetut kielet; unkarin ja japanin kaksisuuntainen oppiminen; kaksikielinen projekti

\section{Mari Okamoto}

562-8558 Aomatani-higashi 8-1-1, Minoo, Osaka, Japan

okamari@lang.osaka-u.ac.jp 